\title{
Evaluating performance in the hotel industry: An empirical analysis of Piedmont
}

\author{
Gabriele Santoro \\ Department of Management, University of Turin, Turin, Italy
}

Email address:

gabriele.santoro@unito.it

To cite this article:

Gabriele Santoro. Evaluating Performance in the Hotel Industry: An Empirical Analysis of Piedmont. Journal of Investment and Management. Special Issue: Attractiveness and Governance of Tourist Destinations. Vol. 4, No. 1-1, 2015, pp. 17-22. doi: 10.11648/j.jim.s.2015040101.13

\begin{abstract}
The hotel industry is a key sector in the tourism industry because it is essential for the supplying of all other tourism services and it is the first service demanded by tourists who reach the destination. To assess hotel's performance appears a hard task, because of the presence of many factors to consider, economic but also less tangible. The aim of the research is to verify the correlation between performance and its determinants in the context of the Piedmont hotel industry, through valuating a sample of 112 hotels of Piedmont. More in particular, the study in vestigates whether variables as stars rating, dimension and added services provided are correlated to performance, measured by Rev Par (revenue per available room), a performance metric typical of the hotel industry. To reach these goals, the research starts with a literature review, on hotel industry in general and on performance evaluation methods more used in hotel industry. Subsequently, it will be explained the methodology and the assumptions. Finally, it will be provided results discussed on a managerial perspective, useless for management to improve quality and performance.
\end{abstract}

Keywords: Tourism, Hotels, Performance, Strategy, Piedmont

\section{Introduction}

The increasing share of the service sector all over the world has raised competition and created new models of competitive advantage sustainability through the provision of high quality services, allowing the development and growth of a territory ([1]; [2]).

In last decades, tourism demand has evolved, creating a whole new generation of tourists, which highlight new specific needs. To satisfy these needs, the areas have to adapt themself and provide the customer a high level of quality.

Tourism services is a very high value for many countries, becoming more important in the actual scenario, where multinational enterprises are competing to reach competitive advantages quickly ([3]; [4]; [5]).

The World Economic Impact Report by the World Travel and Tourism Council [6] shows that tourism industry continues to grow in spite of continuing economic competitiveness.

The direct contribution of tourism industry to GDP in 2013 was USD 2,155.4bn (2.9\% of GDP). This is forecast to rise by $4.3 \%$ to USD 2,248.2bn in 2014. Data reflects the economic activity generated by industries such as hotels, travel agents, airlines and other passenger transportation services (excluding commuter services). It also includes the activities of the restaurant and leisure industries directly supported by tourists. The direct contribution of tourism industry to GDP is expected to grow by $4.2 \%$ pa to USD $3,379.3$ bn (3.1\% of GDP) by 2024.

The total contribution of tourism industry to GDP (including wider effects from investment, the supply chain and induced income impacts, see page 2) was USD 6,990.3bn in $2013(9.5 \%$ of GDP) and is expected to grow by $4.3 \%$ to USD $7,289.1$ bn (9.6\% of GDP) in 2014. It is forecast to rise by $4.2 \%$ pa to USD $10,965.1$ bn by 2024 (10.3\% of GDP).

Tourism industry generated $100,894,000$ jobs directly in 2013 (3.4\% of total employment) and this is forecast to grow by $2.2 \%$ in 2014 to $103,069,000$ (3.4\% of total employment). This includes employment by hotels, travel agents, airlines and other passenger transportation services (excluding commuter services). It also includes the activities of the restaurant and leisure industries directly supported by tourists.

By 2024, tourism industry will account for $126,257,000$ jobs directly, an increase of $2.0 \%$ pa over the next ten years. 
The total contribution of tourism industry to employment (including wider effects from investment, the supply chain and induced income impacts, see page 2) was $265,855,000$ jobs in 2013 ( $8.9 \%$ of total employment). This is forecast to rise by $2.5 \%$ in 2014 to $272,417,000$ jobs (9.0\% of total employment).

By 2024, tourism industry is forecast to support $346,901,000$ jobs (10.2\% of total employment), an increase of $2.4 \%$ pa over the period.

The hotel industry assumes an important value in the tourism industry because it is essential for the provision of all other tourism services and it is the first service demanded by tourists who reach the destination [7]. Furthermore, it carries a high weight in the totality of tourist expenditure.

For these reasons, this paper focuses on the hotel industry within the tourism sector. More particularly, the aim of the research is to verify the correlation between performance and its determinants in the context of the Piedmont hotel industry.

The remainder of the paper is structured as follows. Section 2 discusses the theoretical framework; Section 3 describes the contributions in literature on the determinants of performance in the hotel industry; Section 4 analyzes data about Piedmont tourism; Section 5 explains the research methodology; Section 6 shows the formulation of hypotheses and findings; finally, Section 7 offers conclusions and discussion on a managerial perspective.

\section{Theoretical Framework}

The growth of touristic services demand and the subsequent request for higher standards by the guests has enforced the competition among hospitality suppliers and emphasized how the attractiveness of the touristic destination is influenced by the services provided by the local hotels.

In a such scenario, providing high quality services is the key to improving hotel performance and profitability [8].

Hospitality industry is traditionally more focused on the physical product, but a new customer class is rising, demanding consistent delivery of the brand promise and the experiential dimension.

Hotel is a part of hospitality industry, which counts a wide range of service industries including restaurants, casinos, private clubs, managed food service, event planning, tourism related businesses, and travel providers, and refers to the relationship process between a guest and a host.

Generally speaking, a hotel can be defined as a place where tourist stops being the traveler and becomes a guest.

Technically, a hotel is an establishment that provides lodging paid on a short-term basis and facilities which can range from a basic bed and storage for clothing, to luxury features, so even for the hotels it is important collaborating with firms [9].In many cases, attributes such as price, location, cleanliness, reputation, personal service, and appealing image are decisive by travelers to evaluate the quality of the hotel [10].

It is now known that tourist destinations compete with each other in a competitive arena. In recent years, competition within hospitality industry has increased, as well as that between hotels within a territory.

Consequently, over the years, many hotels started to increase the number of services offered, including suites, public dining, banquet facilities, lounges and entertainment facilities; this has increased the difficulty of the activities management, sometimes moving away from the hotel core competencies [11]. From this point of view, outsourcing is an effective way to manage these difficulties [12].

Therefore, the hotel's management passes through the identification of variables and drivers that increase the results and performance.

\section{Evaluating Performance in the Hotel Industry}

Performance measurement is a basic element of business management to understand the source of sector's competitiveness and support the implementation of strategies.

In general, firm's performance relates to both external and internal factors: external, because firms compete in sectors and markets which influence strategy and results; internal, because firms have to choose strategies to be adopted and, in general, to decide the correct way to operate, to allocate resources in order to manage business functions and reach goals [13].

In recent years, the parameters of performance measurement have changed significantly [14], becoming necessary to join the classics financial indicators with non-financial indicators creating an integrated system of evaluation.

To stay abreast of competition, firms have to consider non-financial and operational aspects [15], such as quality, flexibility and the implementation of new technologies. The limitations in using only financial indicators of performance are that "they are lagged indicators which are the result of management action and organizational performance and not the cause of it"'[16].

Literature provided us many studies on performance indicators, based primarily on firm's financial indicators. Many authors ([17]; [18]) emphasized the empirical contribution on the industrial sector and, subsequently, on service sector. Some features of high intangibility make the hotel industry performance so difficult to analyze, but fascinating at the same time. In fact, there are fewer contributions on hotel management issues ([19]; [20]; [21]).

For the service sector, more than the others, evaluating performance is not just a matter of balance sheet and financial data [22], but is also necessary to consider human resources, quality, brand awareness, image and other non-tangible factors [23].

In the hotel industry, in particular, competition is based on the "total value" offered with the services, so it is necessary to evaluate the various dimension of the value.

Hence, hotel industry performance can be measured using occupancy performance, such as average occupancy rate [24], operating revenues, average production value per employee 
and others indicators.

Several studies have investigated the topic through different interpretations. A first stream of studies have looked for a correlation between performance and external factors. Tang and Jang [25] analyzed the relationship between the performance of four industries linked to tourism (casinos, restaurants, hotels, airlines) and GDP in the U.S. finding no correlation between industry performance and economic growth. Conversely, it is possible to assume that tourism drives economic growth and development [26].

Other research tried to find a correlation between performance and internal factors through using the Balanced Scorecard, which highlights the importance of some internal factors to reach performance [20] and emphasized the importance of internal function like strategy, marketing, production and organization ([27]; [28]).

Among all of the indicators and method listed by now, the research focuses on $\operatorname{RevPAR}([29] ;$ [30]), a performance metric in the hotel industry, which is calculated by dividing a hotel's total guestroom revenue by the room count and the number of days in the period being measured.

The formula of RevPar is:

Total Room Revenue in a Given Period, Net of Discounts, Sales Tax, and Meals number of Available Rooms in Same Period

It provides insight into how well a hotel is utilizing its room inventory, and it is very helpful in trying to price your guest rooms properly.

Furthermore, RevPar is useless to compare performance of the same period (months or year), and to compare performance of different hotels of the same category.

\section{Piedmont Tourism}

The Piedmont region offers a great variety of morphological aspects and natural resources useful to implement processes of local and regional development.

In fact, Piedmont can boasts wonderful territory such as Langhe, Roero and Monferra to Hills, with their sweet landscapes shaped by the combined action of nature and man, which are now UNESCO World Heritage Site. This prove the decision of the Piedmont region to develop a series of initiatives aimed to enhancing tourism, adapting by improving hospitality offering. Actions aimed at strengthening trade capacity and competitiveness of tourism enterprises and actions in support of the overall qualification of the tourist offer.

These policies should and could lead to positive results in the near future, in terms of increase of tourists in Piedmont, Italian and foreign.

Analyzing the situation of the last 10 years, in terms of attendance and arrivals in the region, there has been a substantial increase. More specifically, an increasing of $35.85 \%$ of attendance and $48.92 \%$ of arrivals [31], but at the same time, there is a delay in comparison to some Italian regions.

During the lasts ten years, the peaks have been recorded particularly in July and August, to prove that, even not being a seaside territory, summer tourism in Piedmont has a high potential value.

Even the number of accommodation establishments have increased over the last 10 years $(+60.54 \%)$. These results are mainly due to the XX Olympic Winter Games of 2006, a significant opportunity for the development of the tourism industry in the whole region.

The Piedmont region, in particular, counts nearly eight hundred hotels, of which six hundred of stars rating between three and five, but very few hotels with a rating of five stars.

However, Piedmont suffers competition from other Italian regions also with regard to the social aspect, measured by how many "like" on different social network pages, the frequency of "talk about this" and by the general engagement. From this point of view, the Piedmont is located at the bottom of the ranking, showing not to be in step with current trends and with the entrance of technology even in the tourism sector.

Social networks, and technology in general, are useful for creating community around a territory, and at the same time creating new business within the tourism offer. In this way, even the hotel may enjoy benefits from creating synergies between the territory and enterprises.

\section{Methodology}

The data used in the analysis are taken from the "World Economic Impact Report" by the World Travel and Tourism Council (WTTC, 2014) integrated with data collected on web platforms such as Booking, Expedia, etc. The research was conducted selecting 112 hotels of Piedmont, which have a star rating of three or more (on a rising scale of one to five).

Several studies use RevPar as indicator of the hotel performance due to the fact that it is not an economic variable and it catches the importance of competitive/strategic indicators. RevPAR or revenue per available room, indeed, is a performance metric in the hotel industry, which is calculated by dividing a hotel's total guestroom revenue by the room count and the number of days in the period being measured.

Hence, the purpose of the paper is to verify a correlation between the RevPar and the following variables:

1. Dim = number of available rooms;

2. Category = number of stars of the hotel;

3. Serv $\mathrm{P}=$ binary variable which detects the presence of meeting rooms and congress spaces $(1=$ yes; $2=$ no);

Based on the survey research, data on size, category, and services provided were collected. To better understand the nature of enterprises Table 1 presents the characteristics of the hotels in the sample. 
Table 1. hotels

\begin{tabular}{lll}
\hline Variables & & \\
\hline Size/Dimension (Dim) & Hotels number & $\%$ \\
\hline$<50$ rooms & 66 & $58.9 \%$ \\
$50-79$ rooms & 29 & $25.9 \%$ \\
$>79$ rooms & 17 & $15.2 \%$ \\
Total & $\mathbf{1 1 2}$ & $\mathbf{1 0 0 . 0 \%}$ \\
Category (Stars) & & \\
5 stars & 5 & $4.5 \%$ \\
4 stars & 27 & $24.1 \%$ \\
3 stars & 80 & $71.4 \%$ \\
Total & $\mathbf{1 1 2}$ & $\mathbf{1 0 0 . 0 \%}$ \\
Services provided (ServP) & & \\
yes & 61 & $54.5 \%$ \\
no & 51 & $45.5 \%$ \\
Total & $\mathbf{1 1 2}$ & $\mathbf{1 0 0 . 0 \%}$ \\
\hline
\end{tabular}

Source: primary research results

\section{Hypotheses development}

It is possible to divide the different stream of the literature to verify possible correlations between factors that provide value to hotel offering (category, size, service provided, and location).

Some studies analyzed the relation between size and performance, proving the presence of economies of scale in the industry ([32]; [33]; [34]; [35]; [36]). According to these studies, it is possible to formulate the following hypothesis:

Hpl: there is a positive correlation between hotel dimension and performance.

Other studies found a positive correlation between the category/rating (number of stars) and performance ([37]; [38]; [39]). Considering this authors it is possible to formulate the following hypothesis:

Hp2: there is a positive correlation between the stars-rating (and therefore quality) and performance.

Alternative studies use the presence of facilities like meeting rooms and congress spaces as additional measures of performance, trying to find a correlation between the alternative services provided and performance [40]. Subsequently it is possible to formulate the following hypothesis:

Hp3: there is a positive correlation between the service provided (facilities) and performance.

Table 2 allows us to analyze the possible correlation between the RevPar and the three variables listed above.

Table 2. correlation matrix

\begin{tabular}{llllll}
\hline & & RevPar & Category & Dim & ServP \\
\hline \multirow{3}{*}{ RevPar } & Pearson Correlation & 1 &, $919^{* *}$ &, $472^{* *}$ &, $225^{* *}$ \\
& Sig. (1-tailed) & &, 000 &, 000 &, 000 \\
& N & 112 & 112 & 112 & 112 \\
\hline
\end{tabular}

**. Correlation is significant at the 0.01 level (1-tailed).

Source: research analysis

\section{Findings and Conclusions}

According to Claver-Cortez [35], who has conducted research on the performance of Spanish hotels, hotel's performance improvement should pass through the following strategies:

- increasing the size, because in bigger hotel stands a better chance of generating economies of scale (more rooms to sell) and economies of scope (possibility to offer a wider variety of services in the same establishment);

- belonging to a chain, the affiliation to a chain brings the hotel numerous advantages, for example to greater commercialization capacity, better chances to deliver higher service quality level, the possibility to offer the guest services or more a greater financial capacity to face investment projects;

- increasing category (stars rating) offering more quality

Considering these contributions and comparing it with the collected data, it is possible to draw the following conclusions As it can be seen from the results, all of the variables affect the performance, measured by the RevPar index, but in a different way. In fact, there is a significant correlation between the performance and the category (stars) $(0,919)$, evidence that quality is the first driver of performance in the hotels industry.

There is a significant correlation too between hotel dimension and performance (Hp1) and between services provided and performance ( $\mathrm{Hp} 3)$, but is weaker correlation (respectively 0,472 and 0,225 )

In a managerial perspective, appear clear that quality is the key factor for hotel's performance improvement. Not quality perceived by customers, but quality measured through the national system of assigning stars (category).

Therefore, from the perspective of competitiveness, the hotel management should consider the idea of increasing the size, monitoring the effect and impact of this strategy on the quality provided and then on the stars obtained (category).

Another suggestion for management is to implement TQM in hotel industry having a market-oriented approach. This implies the study of customer's perception and needs, strategies of competitors and policies of training to employees. Market orientation can help hotel design and offer a service mix that customers perceive as superior quality, in turn enhancing hotel performance ([41];[42]).

In conclusion, results seem to confirm the fact that, within the current worldwide scenario, characterized by high competition and rapid erosion of market shares, competition between tourist destinations is affected by quality offered by the hotels in the area. From a managerial perspective, therefore, it appears necessary to provide quality services and pay particular attention to the needs and customer satisfaction. This adds value to the hotel and consequently to the territory.

From a performance evaluation perspective, results confirm the need to take more account of less tangible and qualitative nature indicators.

\section{Acknowledgements}

I would like to express my sincere thanks to Prof. Giuseppe Tardivo for his patience and kindness, who kindly gave me his time helping and encouraging me. Without him, this paper would not have been possible. 


\section{References}

[1] G. Tardivo, S. Bresciani, and M. Cugno, "Sviluppo economico ed infrastrutture: un'analisi empirica delle Province italiane," Sinergie rivista di studi e ricerche (2013).

[2] A. Shani, N. Uriely, A. Reichel, and L. Ginsburg, "Emotional labor in the hospitality industry: The influence of contextual factors." International Journal of Hospitality Management, vol. 37, 2014, pp. 150-158.

[3] G.M. Golinelli, L'approccio sistemico al governo dell'impresa, vol. III, Padova: Cedam, 2008.

[4] G. Tardivo, "L'evoluzione degli studi sul Knowledge Management”, Sinergie, no. 76, 2008, pp. 21-42.

[5] S. Bresciani, and A. Ferraris, Imprese Multinazionali: Innovazione e Scelte Localizzative, Santarcangelo di Romagna (RN): Maggioli, 2012.

[6] World Travel and Tourism Council (2014), World Economic Impact Report, World Travel and Tourism Council http://www.wttc.org/.

[7] F. Orfila-Sintesa, R. Crespi-Cladera, and E. Martinez-Ros, "Innovation activity in the hotel industry: Evidence from Balearic Islands", Tourism Management, vol. 26, no. 6, 2005, pp. 851-865.

[8] M. Oppermann, "Destination Threshold Potential and the Law of Repeat Visitation", Journal of Travel Research, vol. 37, no. 2, 1998, pp. 131-137.

[9] M. Arnaboldi, and N. Spiller,"Actor-network theory and stakeholder collaboration: The case of Cultural Districts," Tourism Management, vol. 32, no. 3, 2011, pp. 641-654.

[10] J. Barsky, and R. Labagh, "A strategy for customer satisfaction," The Cornell Hotel and Restaurant Administration Quarterly, vol. 35, no. 3, 1992, pp. 32-40.

[11] N. Hemmington, and C. King, "Key dimensions of outsourcing hotel food and beverage services," International Journal of Contemporary Hospitality Management, vol. 12, no. 4, 2000, pp. 256-261.

[12] G. Gonzalez-Rivera, "Outsourcing: three long run predictions," Global Business and Economics Review, vol. 7, no. 2/3, 2005, pp. $226-233$.

[13] S. Bresciani, A. Thrassou, and D. Vrontis, "Human Resource Management - Practices, Performance and Strategy in the Italian Hotel Industry," World Review of Entrepreneurship, Management and Sustainable Development, vol. 8, no. 4, 2012, pp. 405-423.

[14] A. Neely, and M. Bourne, "Why measurement initiatives fail," Measuring Business Excellence, vol. 5, no. 2, 2000, pp. 6-13.

[15] B.A. Hu, and A.C. Cai, "Hotel labor productivity assessment: a data envelopment analysis," Journal of Travel and Tourism Marketing, vol. 16, 2004, pp. 27-38.

[16] S. Brignall, and J. Ballantine, "Performance Measurement in Service Businessess Revisited," International Journal of Service Industry Management, vol. 7, no. 1, 1996,pp. 6-31.

[17] N. Evans, "A resource-based view of outsourcing and its implications for organizational performance in the hotel sector," Tourism Management, vol. 26, no. 5, 2005, pp. 707-21.
[18] K.H. Kang, S. Lee, and C. Huh, "Impacts of positive and negative corporate social responsibility activities on company performance in the hospitality industry," «International Journal of Hospitality Management», vol. 29, no. 1, 2010, pp. 72-82.

[19] R. Chenhall, "Theorizing contingencies in management control systems research," in Handbook of Management Accounting Research, C. Chapman, A. Hopwood, and M. Shields, Eds. Amsterdam: Elsevier, 2007.

[20] R. Sainaghi, "Hotel performance: state of the art," International Journal of Contemporary Hospitality Management, vol. 22, no. 7, 2010, pp. 920-952.

[21] R. Sainaghi, and R. Baggio. "Structural social capital and hotel performance: Is there a link?." International Journal of Hospitality Management, vol. 37, 2014, pp. 99-110.

[22] A. Ghalayini, and J. Noble, "The changing basis of performance measurement," International Journal of Operations and Production Management, vol. 16, no. 8, 1996, pp. $63-80$.

[23] A. Thrassou, and D. Vrontis, "A New Consumer Relationship Model: The Marketing Communications Application," Journal of Promotion Management, vol. 15, Issue 4, 2009, pp. 499-521.

[24] S. Sun, and W. Lu, "Evaluating the performance of the Taiwanese hotel industry using a weight slacks-based measure," Asia-Pacific Journal of Operational Research, vol. 22, no. 4, 2005, pp. 487-512.

[25] C.H. Tang, and S.C. Jang, "The tourism-economy causality in the United States: A sub-industry level examination," Tourism Management, vol. 30, no. 4, 2009, pp. 553-558.

[26] J.G. Brida, J.S. Pereyra, M.J. Such, and M. Pulina, "Causality between tourism and long-term economic growth: a critical review of the econometric literature," MPRA Paper No. 37332, April 2011.

[27] H.B. Kim, and W.G. Kim, "The relationship between brand equity and firms' performance in luxury hotels and chain restaurants," Tourism Management, vol. 26, no. 4, 2005, pp. 549-560.

[28] T. Øgaard, E. Marnburg, and S. Larsen, "Perceptions of organizational structure in the hospitality industry: consequences for commitment, job satisfaction and perceived performance," Tourism Management, vol. 29, no. 4, 2008, pp. 661-671.

[29] K. Namasivayam, L. Miao, and X. Zhao, “An investigation of the relationships between compensation practices and firm performance in the US hotel industry," International Journal of Hospitality Management, vol. 26, no. 3, 2007, pp. 574-587.

[30] A. Campos Blanco, A. Oehmichen, A. and S. Frood, "European hotel development - Focus on budget hotels," Journal of Retail \& Leisure Property, vol. 9, no. 5, 2011, pp. 373-379.

[31] Dati statistici del turismo in Piemonte-anno 2013. http://www.regione.piemonte.it/

[32] A.A. Israeli, "Star rating and corporate affiliation: their influence on room price and performance of hotels in Israel," International Journal of Hospitality Management, vol. 21, no. 4, 2002, pp. 405-424.

[33] C.P. Barros, "A stochastic cost frontier in the Portuguese hotel industry," Tourism Economics, vol. 10, no. 2, 2004, pp. 177-192. 
[34] R. Pine, and P.A. Phillips, "Performance comparisons of hotels in China," International Journal of Hospitality Management, vol. 24, no. 1,2005 , pp. 57-73.

[35] E. Claver-Cortés, J.F. Molina-Azorìn, and J. Pereira, J. "The impact of strategic behaviours on hotel performance," International Journal of Contemporary Hospitality Management, vol. 19, no. 1, 2007, pp. 6-20.

[36] A. Assaf, and L.K. Cvelbar, "The performance of the Slovenian hotel industry: evaluation post-privatisation," International Journal of Tourism Research, vol. 12, no. 5, 2010, pp. 462-471.

[37] P. Ingram, and P.W. Roberts, "Friendships among Competitors in the Sydney Hotel Industry," American Journal of Sociology, vol. 106, no. 2, 2000, pp. 387-423.

[38] S. Danziger, A. Israeli, and M. Bekerman, "The relative role of strategic assets in determining customer perceptions of hotel room price," International Journal of Hospitality Management, vol. 25, no. 1, 2006, pp. 129-145.
[39] J.J. Tarí, E. Claver-Cortés, J. Pereira-Moliner, J., and J.F. Molina-Azorín, "Levels of quality and environmental management in the hotel industry: Their joint influence on firm performance," International Journal of Hospitality Management, vol. 29, no. 3, 2010, pp. 500-510.

[40] A. Urtasun, and I. Gutíerrez, "Hotel location in tourism cities. Madrid 1936-1998," Annals of Tourism Research, Vol. 33, No. 2, 2006, pp. 382-402.

[41] R.C.M. Yam, A.Y.K. Tam, E.P.Y. Tang, C.K. Mok, "TQM: a change management model or market orientation," Total Quality Management \& Business Excellence, vol. 16, no. 4, 2005, pp. 439-461.

[42] C.H. Wang, K.Y. Chen, and S.C. Chen, "Total quality management, market orientation and hotel performance: the moderating effects of external environmental factors," International Journal of Hospitality Management, vol. 31, no. 1, 2012, pp. 119-129. 